\title{
Obituary
}

\section{Emeritus Professor H. D. Kay, G.B.E., Ph.D. (Cantab), D.Sc. (Manchester), F.R.S.}

Herbert Davenport Kay, Director of the National Institute for Research in Dairying and Research Professor of Biochemistry in the University of Reading from 1933 until his retirement in 1958, died peacefully at his home in Caversham on 24 November 1976 at the age of 83 .

Herbert Kay was born in Lancashire in 1893; he was educated first at Manchester Grammar School and then at the University of Manchester where he graduated in 1914 with First Class Honours in Chemistry, including Biochemistry, and became Leblanc Medallist and University Scholar.

Like most of his generation, Kay went from University to the trenches and was in France until wounded in 1916. He then joined Command Gas School, Aldershot, eventually becoming Chemical Adviser to G.H.Q., Home Forces, from November 1918 until July 1919. He was twice mentioned in despatches and was awarded a Military O.B.E. in 1919.

Resuming his academic studies in 1919, his first post was as Demonstrator in Biochemistry in the University of Leeds, where he stayed until, in 1921, he was awarded a Beit Memorial Fellowship for Medical Research which enabled him to work for 2 years at the Lister Institute of Preventive Medicine and to spend 6 months in Freiburg, Germany, before returning to England to work under Professor Sir Frederick Gowland Hopkins, F.R.S., in Cambridge. He obtained his Ph.D. (Cambridge) in 1925 and was appointed Biochemist to the Medical Unit at the London Hospital and a Senior Beit Fellow. He was awarded his D.Sc. (Manchester) in 1926. In 1929, Kay moved to the University of Toronto to take up an appointment as Associate Professor of Biochemistry and he became full Professor in 1931. A year later he was invited to become the second Director of the National Institute for Research in Dairying and Research Professor of Biochemistry in the University of Reading; he returned from Canada and took up these posts on 1 January 1933.

During the 13 or so years that Kay was working full-time at the bench he published more than 50 papers; the quantity and quality of this published work provide a most impressive record of his personal research achievements. His first papers were concerned with the mode of oxidation of branched-chain fatty acids, but his interests soon turned towards the role of phosphorus compounds in metabolism and he rapidly became established as one of the leading workers studying the occurrence and distribution of phosphorus compounds in body tissues and the activity and role of phosphatases in regulating the metabolism of phosphate esters in health and disease.

Although Kay had noted in 1925 that the mammary gland contained an enzyme which hydrolysed the acid-soluble phosphate esters of milk, it was not until 1933 that he reported from Toronto (with W. R. Graham Jr) the presence of a phosphatase in milk and that 'the pasteurization process appeared to destroy the enzyme'. In the following paper they described qualitative and quantitative methods for determining 
phosphatase in milk that offered a simple means of differentiating between raw and pasteurized milk and milk products. Subsequently, Graham joined Kay at the N.I.R.D., the methods were improved and simplified, and the classic paper describing the Kay-Graham Phosphatase Test for Pasteurization was published in this Journal in 1935. As is well known, the phosphatase test soon gained acceptance throughout the world as the most reliable means of confirming effective pasteurization.

When Professor Kay took up his appointment at the N.I.R.D. in 1933 the Institute had been established at Shinfield for just 10 years. During this time Dr Stenhouse Williams, the first Director, and his small band of colleagues had devoted much of their research effort to necessary and essentially ad hoc problems concerned with the improvement of methods for the production and handling of milk and for the chemical analysis of milk. However, by 1933 it had become apparent that many of the other problems in the dairy industry could only be resolved when more knowledge had been gained of the basic principles underlying dairy science, and, in particular, of those concerned with the physiology of lactation and the biochemistry of milk secretion. Kay immediately devoted himself with characteristic drive and determination to his first and enduring task, that of winning the necessary resources for buildings, staff and equipment to extend the Institute's research programmes. Financial difficulties were successfully overcome and his years at the N.I.R.D. saw it grow from a total staff of 47 housed in an old Manor House to a modern, well-equipped Institute with some 340 staff, 700 acres of land and 400 cattle, and acquire an international reputation. In these formative years Kay provided opportunity, encouragement and inspiration for many of those who now occupy responsible posts in the Institute he built and in many research and educational organizations throughout the world. Perhaps one of his particular achievements as Director was his early success in establishing the value of the team or collaborative approach to the solution of research problems, both within the Institute and in joint research with other organizations.

Whilst he was Director administrative duties severely restricted the time and opportunities that Kay had to develop new personal research interests. He did, however, succeed (with Graham) in developing techniques for simultaneously sampling arterial and mammary venous blood that enabled them to carry out some of the first reported experiments to determine the precursors in blood of milk constituents. This subject of 'blood-milk relationships' remained of abiding interest to him and in later years many of his colleagues recall being constantly encouraged to follow his lead.

Another subject that remained very dear to his heart was the value of milk as a food. As a member of the Milk Nutrition Committee he was closely concerned with the classic series of experiments planned and carried out in 1934-36 that resolved a longoutstanding controversy by showing that pasteurization did not significantly reduce the nutritive value of milk; the experiments also confirmed that a daily allowance of two-thirds of a pint of milk consistently improved the growth and health of young children. An important outcome of these findings was an increased public awareness of the value of milk as food: more milk was drunk and milk came to take an increasingly important part in the national diet, particularly during the Second World War. Kay recognized that if milk was properly to fulfil its role in the diet it must be both 


\section{Obituary}

of good hygienic and of good compositional quality, and he was one of the earliest advocates of the payment for milk on the basis of quality rather than quantity. In pursuing this aim he was closely involved with the foundation and development of the National Milk Testing and Advisory Service, and he was largely responsible for the establishment near the N.I.R.D. of the Reading Cattle Breeding Centre.

Kay was constantly seeking opportunities to make known to a wider audience both the problems of the dairy industry and the results of research aimed at solving them. He published more than 100 such general articles in scientific journals and in the technical and farming press. (His masterly skill with the pen is nowhere better exemplified than by the Biographical Memoirs of Lord Boyd Orr, Sir William Slater and the 2nd Earl Iveagh that he wrote for the Royal Society.) He was largely responsible for the establishment at the N.I.R.D. of the Commonwealth Bureau of Dairy Science, of which he was the first Director.

$\mathrm{He}$ also made very substantial contributions to the work of learned societies. He was elected to the Royal Society in 1945, and he later became a member of its Council and of a number of its Committees. He was a Trustee of the Biochemical Society, Vice-President of the Society of Chemical Industry and Chairman of the Microbiology Group and of the Food Group of that Society. He was for many years a staunch supporter of the British Association for the Advancement of Science, President of Section M (Agriculture) and a member of Council. As Founder-President of the Society of Dairy Technology he also served on its Council and its Education and Research Committee, and his long and valuable service to the Society was recognized in 1957 by the rare award of the Society's Gold Medal.

Professor Kay was appointed Commander of the Order of the British Empire in 1946 and he was awarded the Coronation Medal in 1953.

In the international field Kay was always generous in his help to organizations concerned with the efficient production and processing of food for the population of the world and he gave conspicuous service to the Food and Agriculture Organization, the World Health Organization and the United Nations International Children's Emergency Fund. In 1946 he went to India for 3 months to advise the Indian Government on problems of dairy research, and it was following his report that the National Dairy Research Institute at Karnal was founded. He also worked actively for the International Dairy Federation, being for many years a member of its Executive Committee and President of the Commission of Studies.

After his retirement from the Institute in 1958, Kay spent 5 years planning and directing the Twyford Laboratories where he greatly enjoyed his opportunity once again to build up a team of biochemists who were keen to use basic science in the solution of applied problems. He continued to serve on numerous committees and to give close and critical attention to various physiological and nutritional topics that were of particular interest to him. One such was the biochemical role of copper, both in plants and animals, and at the time of his death he was still consultant to the International Copper Research Association. Shortly before his death, he was an active participant in symposia at the Zoological Society and the Royal Society.

To his staff Herbert Kay was a kind and friendly Director, always ready with advice and encouragement. His many commitments left him little time for leisure, but he had a wide knowledge of literature; for over 40 years he was a member of the 
1872 Book Club, a group of 9 Reading men which, despite its title, is also a dining and conversation club. He was one of its outstanding conversationalists and his proposals for books for circulation reflected his wide interests, ranging from astronomy to detective and science fiction; the book he last proposed was an anthology of limericks.

His persistent vitality can perhaps be ascribed to his belief in the value of physical exercise and his lifelong enthusiasms for walking and gardening. Unlike most of his colleagues, Kay seldom travelled to work by car; his customary habit was to take a short bus journey and then to walk the last mile to the N.I.R.D; he would always refuse a lift, even in the dirtiest weather. His lunch-time walks took him around the Institute's farms and his familiar figure striding vigorously across the fields will be remembered by many with affection. He was a keen and successful gardener, an interest he shared with his wife, herself a botanist, and besides the sizeable garden around his house he also cultivated a nearby allotment. For many years he was President of the Reading Horticultural Federation. A few years ago, when he moved from his house in Christchurch Gardens to a smaller one in Caversham, he quickly and enthusiastically replanned the garden to make room for a vegetable plot on which he could grow a full range of crops.

He leaves a widow and four sons. His happy family life did much to sustain him in his demanding professional duties.

J. W. G. PORTER 